\title{
Structural Features Determining Differential Receptor Regulation of Neuronal Ca Channels
}

\author{
Arthur A. Simen and Richard J. Miller \\ Department of Pharmacological and Physiological Sciences, Committee on Neurobiology, University of Chicago, \\ Chicago, Illinois 60637
}

\begin{abstract}
Dihydropyridine-insensitive $\mathrm{Ca}$ channels are subject to direct receptor G-protein-mediated inhibition to differing extents. $\alpha_{1 \mathrm{~B}}$ channels are much more strongly modulated than $\alpha_{1 \mathrm{E}}$ channels. To understand the structural basis for this difference, we have constructed and expressed various $\alpha_{1 \mathrm{~B}}$ and $\alpha_{1 \mathrm{E}}$ chimeric $\mathrm{Ca}$ channels and examined their regulation by $\kappa$-opioid receptors. Replacement of the first membrane-spanning domain of $\alpha_{1 \mathrm{E}}$ with the corresponding region of $\alpha_{1 \mathrm{~B}}$ resulted in a chimeric $\mathrm{Ca}$ channel that was modulated by $\kappa$-opioid receptors to a
\end{abstract}

Voltage-sensitive $\mathrm{Ca}$ channels are one of the most important classes of molecules used by excitable cells for the transduction of cellular excitability into the intracellular $\mathrm{Ca}$ signals that regulate events such as muscle contraction and the release of neurotransmitters. Inhibition of $\mathrm{Ca}$ influx through these channels by G-protein-linked receptors is an important means by which neurotransmitters and drugs can regulate the strength of synaptic transmission (Miller, 1990; Rhim et al., 1994). Elucidation of the primary structure of $\mathrm{Ca}$ channels has demonstrated that they consist of a family of related proteins that has two branches. Each branch consists of three different proteins that differ in their pharmacology and, in particular, in their sensitivity to dihydropyridine (DHP) drugs. It is thought that the subfamily of DHPinsensitive $\mathrm{Ca}$ channels can be regulated by receptors through the direct interaction of G-protein $\beta \gamma$ subunits with the major poreforming $\left(\alpha_{1}\right)$ subunit of the channel (Herlitze et al., 1996; Ikeda, 1996; De Waard, 1997; Zamponi et al., 1997). Expression studies have indicated that all three types of DHP-insensitive Ca channels $\left(\alpha_{1 \mathrm{~A}}, \alpha_{1 \mathrm{~B}}\right.$, and $\left.\alpha_{1 \mathrm{E}}\right)$ are regulated by G-proteins, although there are large differences in their susceptibility to modulation. Thus, $\alpha_{1 \mathrm{~B}}$ is the most sensitive to G-protein modulation, and $\alpha_{1 \mathrm{E}}$ is the least sensitive (Toth et al., 1996; Yassin et al., 1996).

The structural basis for the $\mathrm{G}$-protein regulation of $\mathrm{Ca}$ channels has received considerable attention, and recent studies have started to reveal the sites of interaction between G-protein $\beta \gamma$ subunits and $\mathrm{Ca}$ channels. Initially, it was shown that G-protein $\beta \gamma$ subunits could interact with two distinct sites in the intracel-

Received Nov. 12, 1997; revised March 2, 1998; accepted March 4, 1998.

This work was supported by Public Service Grants DA02121, DA02575, MH40165, NS33502, DK42086, and DK44840. A.A.S. was supported by Public Service Grants HD07009 and DA02575. We are grateful to Dr. R. Harpold (Sibia Neurosciences) for the Ca channel subunits used in these studies and to Dr. G. I. Bell (Howard Hughes Medical Institute, University of Chicago) for helpful discussions regarding the molecular techniques used in these studies, for the use of his laboratory facilities, and for the opioid receptor clones used in this work.

Correspondence should be addressed to Dr. Richard J. Miller, Department of Pharmacological and Physiological Sciences, University of Chicago, 947 East 58th Street, Chicago IL 60637.

Copyright (C) 1998 Society for Neuroscience $\quad 0270-6474 / 98 / 183689-10 \$ 05.00 / 0$ significantly greater extent than $\alpha_{1 \mathrm{E}}$. Transfer of the $\mathrm{N}$ terminus and I/II loop from $\alpha_{1 \mathrm{~B}}$ in addition to domain I resulted in a chimeric channel that was modulated to the same extent as $\alpha_{1 \mathrm{~B}}$. Other regions of the molecule do not appear to contribute significantly to the degree of inhibition obtained, although the $\mathrm{C}$ terminus may contribute to facilitation.

Key words: calcium channels; G-proteins; opioid receptors; modulation; structure-function; inverse agonism lular loop connecting the first two domains of the $\alpha_{1}$ subunit (I/II loop) (De Waard et al., 1997; Qin et al., 1997; Zamponi et al., 1997). One of these sites contains the QXXER motif, which has been shown to be important in the binding of $\beta \gamma$ subunits to other effectors (Pragnell et al., 1994; Chen et al., 1995). However, although there is little doubt that $\beta \gamma$ subunits can interact with this region of the channel, controversy exists as to the significance of this interaction. Experiments designed to demonstrate the importance of this interaction for G-protein regulation of $\mathrm{Ca}$ channels have yielded mixed results. Further studies have indicated that $\beta \gamma$ subunits can also bind to a region in the $\mathrm{C}$-terminal tail of sensitive Ca channels (Qin et al., 1997), and there are data suggesting that this interaction may be important in G-protein modulation (Qin et al., 1997; Z hang et al., 1996). In either case, because binding to these sites is a common element to all three DHP-insensitive Ca channels, further structural features are likely to be required to determine differential sensitivity to G-proteins. To identify structural elements involved in determining the differential sensitivity of $\alpha_{1 \mathrm{~B}}$ compared with $\alpha_{1 \mathrm{E}}$ channels, we have created a variety of chimeric Ca channels in which different parts of $\alpha_{1 \mathrm{~B}-1}$ were transferred into an $\alpha_{1 \mathrm{E}-3}$ background. Exchange of domain I alone yields a chimeric channel with considerably increased sensitivity to modulation, but the further exchange of the $\mathrm{I} / \mathrm{II}$ linker and the $\mathrm{N}$ terminus is required to obtain a chimeric channel with sensitivity to modulation equivalent to native $\alpha_{1 \mathrm{~B}-1}$. Transfer of the $\mathrm{C}$ terminus of $\alpha_{1 \mathrm{~B}-1}$ appears to enhance facilitation but not inhibition.

\section{MATERIALS AND METHODS}

Cell culture. tsA-201 cells (a gift from Dr. W. A. Horne, Stanford University) were cultured in MEM (Life Technologies, Gaithersburg, MD), $10 \%$ fetal bovine serum (Life Technologies), and $1 \%$ penicillinstreptomycin (Life Technologies) at $37^{\circ} \mathrm{C}$ in $5 \% \mathrm{CO}_{2}$. When cells reached $40-70 \%$ confluency they were replated in $35 \mathrm{~mm}$ dishes and were transfected $4-10 \mathrm{hr}$ later with a total of 5-7 $\mu \mathrm{g}$ of DNA $(2-5 \mu \mathrm{g}$ of $\alpha_{1}, 1.7 \mu \mathrm{g}$ of $\alpha_{2 \mathrm{~B}}, 0.8 \mu \mathrm{g}$ of $\beta_{1 \mathrm{~B}}, 1.5 \mu \mathrm{g}$ of $\kappa_{1} \mathrm{R}$ or $\delta \mathrm{R}$, and $1 \mu \mathrm{g}$ of CD8- $\alpha$ ) by polyethyleneimine-mediated transfection (Boussif et al., 1996). Cells were washed with culture medium 1-2 hr after transfection, and fresh $10 \%$ serum-containing medium was added. Cells were detached from 
dishes with HBSS (Ca- and Mg-free; Life Technologies) 30-40 hr later and were replated on poly-L-lysine-coated coverslips. Cells were recorded from 36 to $80 \mathrm{hr}$ after transfection. cDNA for CD8 $\alpha$ was a gift from Dr. J. Bluestone (University of Chicago). The $\kappa_{1} R$ and $\delta \mathrm{R}$ constructs were gifts from Dr. G. I. Bell (Howard Hughes Medical Institute, University of Chicago) and have been described previously (Yasuda et al., 1993). Expression of $\alpha_{2 \mathrm{~B}}$ and $\beta_{1 \mathrm{~B}}$ were verified by reverse transcription-PCR and Northern blotting (data not shown).

Electrophysiology. Currents were recorded in a solution containing 15 $\mathrm{mM} \mathrm{BaCl}_{2}\left(5 \mathrm{mM} \mathrm{BaCl}_{2}\right.$ in the case of the current-voltage data), $150 \mathrm{mM}$ TEA-Cl, and $10 \mathrm{~mm}$ HEPES, pH 7.4, with TEA-OH or $N$-methyl-Dglucamine. Pipette solutions were made according to the method of Bean (1992). U69593 (Sigma, St. Louis, MO; or Research Biochemicals, Natick, MA) and norbinaltrophimine (norBNI; Research Biochemicals) were made as concentrated stock solutions in 100\% ethanol. ICI-174,864 was made as a $10 \mathrm{~mm}$ stock solution in DMSO. [D-Pen ${ }^{2,5}$ ]-enkephalin (DPDPE) was made as a $10 \mathrm{~mm}$ stock solution in sterile water. U69593, DPDPE, and ICI-174864 were added to the bath solution at concentrations of $1 \mu \mathrm{M}$, and norBNI was added at $100 \mathrm{nM}$. Data were recorded under the control of pClamp6 software (Axon Instruments, Foster City, CA) with an Axon 200A amplifier at an acquisition rate of $10 \mathrm{kHz}$ and were filtered with a four-pole Bessel filter at $2 \mathrm{kHz}$. Pipettes were typically $1-3 \mathrm{~m} \Omega$ in resistance, and series resistance was compensated $>80 \%$ in all cases. To assay G-protein modulation, currents were elicited by a dual-pulse protocol consisting of two $50 \mathrm{msec}$ depolarizations to 0 $\mathrm{mV}$ from a holding potential of $-90 \mathrm{mV}$, separated by $800 \mathrm{msec}$ at the holding potential, with a $30 \mathrm{msec}, 90 \mathrm{mV}$ depolarization (prepulse) ending $5 \mathrm{msec}$ before the second pulse. Cells expressing CD8 $\alpha$ were identified by incubation with anti-CD8 $\alpha$-coated beads (Dynal, Great Neck, NY), and bead-decorated cells were chosen exclusively for recordings.

Data analysis. Data were analyzed off-line using Clampfit (Axon Instruments), Systat (SPSS Inc., Chicago, IL), MATLAB (MathWorks Inc.), and custom-written software. Current inhibition was estimated as follows. Peak current amplitudes were measured and were adjusted to remove any slow linear "runup" or "rundown" by subtraction of linear function fits to the baselines. A series of adjacent current amplitudes was averaged just before drug exposure, during U69593 exposure at the peak of the drug effect, and during the peak of the norBNI response. Currents in the presence of U69593 were taken as an estimate of current in the presence of maximally activated receptor $I\left(\mathrm{R}^{*}\right)$. When norBNI caused amplitudes to increase beyond baseline values before drug exposure, currents were taken as an estimate of current in the presence of maximally inactive receptor $I(\mathrm{R})$. Otherwise, baseline values were used to estimate $I(\mathrm{R})$. "Total modulation" was then defined as $\left[I(\mathrm{R})-I\left(\mathrm{R}^{*}\right)\right] / I(\mathrm{R})$.

Relief of inhibition by the depolarizing prepulse was quantified by calculating a "corrected prepulse ratio" to allow for comparisons between constructs while correcting for differences in inactivation caused by the prepulse. Current ratios in the presence of U69593, I (+pp)/ $I(-\mathrm{pp})$, were calculated and corrected for differences in inactivation between constructs by multiplying by the ratio $I(-p p) / I(+p p)$ in the presence of norBNI. Facilitation was expressed as a simple current ratio, $I(+\mathrm{pp}) / I(-\mathrm{pp})$, for the purpose of describing the intrinsic receptor activity of the $\kappa_{1} \mathrm{R}$ with respect to $\alpha_{1 \mathrm{~B}-1}$ currents.

Unless otherwise noted, comparisons between the constructs in terms of current inhibition and relief of inhibition were conducted by means of a one-way ANOVA followed by post hoc analysis by the Tukey multiplecomparison procedure (Neter et al., 1985). Averages were expressed as mean \pm SEM.

Construction of cDNAs. The chimeric contructs were created using overlap extension PCR (Ho et al., 1989; Horton et al., 1989, 1990) and PCR-mediated site-directed mutagenesis. PCR products were cloned into pGEM-T (Promega, Madison, WI), pGEM-T-EZ (Promega), or pT7-Blue (Novagen, Madison, WI) and sequenced using semiautomated DNA sequencing (ABI 377; Perkin-Elmer, Oak Brook, IL). All $\alpha_{1}$ subunit expression contructs were created by ligation of recombinant and native sequences into the pcDNA3.1 expression vector (Invitrogen, San Diego, CA). Final constructs were confirmed by a combination of restriction analysis and DNA sequencing. The native $\alpha_{1 \mathrm{~B}-1}$ construct $\mathrm{bBbBbBbBb}$ consisted of residues 1-2340 of GenBank accession number 284339 (a gift from Dr. R. Harpold, SIBIA Neurosciences). The native $\alpha_{1 \mathrm{E}-3}$ construct eEeEeEeEe consisted of residues 1-2271 of GenBank accession number 1082919 (a gift from Dr. R. Harpold, SIBIA Neurosciences). The construct bBbBbEeEb consisted of $\alpha_{1 \mathrm{~B}-1} 1-1145, \alpha_{1 \mathrm{E}-3}$ $1149-1724$, and $\alpha_{1 \mathrm{~B}-1} 1710-2340$. The construct bBbBbEeEe consisted of $\alpha_{1 \mathrm{~B}-1} 1-1145$ and $\alpha_{1 \mathrm{E}-3} 1149-2271$. The construct bBbEeEeEe consisted of $\alpha_{1 \mathrm{~B}-1} 1-482$ and $\alpha_{1 \mathrm{E}-3} 477-2271$. The construct eBbEeEeEe consisted of $\alpha_{1 \mathrm{E}-3} 1-89, \alpha_{1 \mathrm{~B}-1} 96-482$, and $\alpha_{1 \mathrm{E}-3}$ 477-2271. The construct eBeEeEeEe consisted of $\alpha_{1 \mathrm{E}-3} 1-89, \alpha_{1 \mathrm{~B}-1} 96-355$, and $\alpha_{1 \mathrm{E}-3} 351-2271$. The construct eEbEeEeEe consisted of $\alpha_{1 \mathrm{E}-3} 1-350, \alpha_{1 \mathrm{~B}-1} 356-482$, and $\alpha_{1 \mathrm{E}-3}$ 477-2271. The construct eEbBbEeEe consisted of $\alpha_{1 \mathrm{E}-3} 1-350$, $\alpha_{1 \mathrm{~B}-1} 356-1145$, and $\alpha_{1 \mathrm{E}-3} 1149-2271$. The construct eEeEbEeEe consisted of $\alpha_{1 \mathrm{E}-3} 1-703, \alpha_{1 \mathrm{~B}-1} 710-1145$, and $\alpha_{1 \mathrm{E}-3} 1149-2271$. The construct eEbEbEeEe consisted of $\alpha_{1 \mathrm{E}-3} 1-350, \alpha_{1 \mathrm{~B}-1} 356-482, \alpha_{1 \mathrm{E}-3} 477-703, \alpha_{1 \mathrm{~B}-1}$ $710-1145$, and $\alpha_{1 \mathrm{E}-3} 1149-2271$. The construct $\mathrm{e}\left(\mathrm{E}_{90-309} \mathrm{~B}_{315-}\right.$ $355) \mathrm{bEeEeEe}$ consisted of $\alpha_{1 \mathrm{E}-3} 1-309, \alpha_{1 \mathrm{~B}-1} 315-482$, and $\alpha_{1 \mathrm{E}-3} 477-$ 2271. The $\alpha_{2 \mathrm{~B}} / \delta$ and $\beta_{1 \mathrm{~B}}$ Ca channel subunit cDNAs were gifts from Dr. R. Harpold (Sibia Neurosciences) and were subcloned into the pCMV6c expression vector.

\section{RESULTS \\ Intrinsic activity of the $\kappa$-opioid receptor and effects on $\alpha_{1 \mathrm{~B}}$ and $\alpha_{1 \mathrm{E}}$}

After transfection of tsA201 cells (Margolskee et al., 1993) with the Ca channel subunits $\alpha_{1-\mathrm{B} 1}, \beta_{1 \mathrm{~B}}$, and $\alpha_{2 \mathrm{~B}}$, the $\kappa_{1}$-opioid receptor $\left(\kappa_{1} \mathrm{R}\right)$, and $\mathrm{CD} 8 \alpha$, we observed that $\alpha_{1-\mathrm{B} 1}$ currents often showed a degree of prepulse facilitation, suggestive of G-proteinmediated inhibition, even without previous exposure to $\kappa_{1} \mathrm{R}$ agonists (Fig. $1 A, B$ ). Overall, $62 \%$ of $\alpha_{1 \mathrm{~B}-1^{-}}$and $\kappa_{1 \mathrm{R}}$-transfected cells responsive to $\kappa_{1} \mathrm{R}$ agonists showed some degree of facilitation before drug exposure. These effects were not seen in cells incubated overnight with $100 \mathrm{ng} / \mathrm{ml}$ pertussis toxin $(n=5)$ or in cells that were not transfected with the $\kappa_{1} \mathrm{R}$ receptor $(n=6)$, suggesting a receptor-mediated, G-protein $\left(\mathrm{G}_{\mathrm{i}}\right.$ and/or $\left.\mathrm{G}_{\mathrm{o}}\right)$-dependent mechanism (data not shown). Similar G-protein receptordependent modulation of $\mathrm{Ca}$ channels in the absence of agonist has been described by other groups (Ikeda, 1992; Zhang et al., 1996). The effects seen in the present study did not diminish when cells remained in a rapidly flowing bath for longer than $20 \mathrm{~min}$, suggesting that agonist-independent modulation was not caused by the secretion of opioid agonists by the cells or the presence of opioid agonists in the culture media (Doupnik et al., 1994). U69593 is a $\kappa_{1} \mathrm{R}$-selective agonist with an affinity for $\kappa_{1}$ receptors in the range of 1-2 nм (Avidor-Reiss et al., 1995; Simonin et al., 1995) and an $\mathrm{EC}_{50}$ for adenylyl cyclase inhibition of $\sim 8 \mathrm{nM}$ (Avidor-Reiss et al., 1995). When U69593 was added to the bath solution at a supramaximal concentration of $1 \mu \mathrm{M}, \alpha_{1-\mathrm{B} 1}$ expressing cells showed a marked reduction in current (Fig. $1 A$ ) ( $47 \pm 6.4 \% ; n=13)$, similar to the results of a number of other groups (Kaneko et al., 1994; Tallent et al., 1994; Carpenter et al., 1996; Toth et al., 1996). When the $\kappa_{1}$ R-selective "antagonist" norBNI (Portoghese et al., 1987) was added directly after U69593 exposure at a concentration of $100 \mathrm{nM}$, the inhibition produced by the agonist was always relieved within 3-4 min (Fig. 1A,B), and currents often increased in magnitude beyond those seen before U69593 exposure (Fig. 1A,B) $(n=13)$. When U69593 was added to cells without subsequent addition of norBNI, current inhibition and facilitation washed out in $\sim 10 \mathrm{~min}$, and no enhancement of current amplitudes was observed (data not shown) $(n=5)$. When norBNI was added to $\kappa_{1} \mathrm{R}$ expressing cells that showed facilitation without previous agonist exposure, this facilitation was always reversed, and currents were always observed to increase in amplitude (Fig. 1C) $(n=5)$. However, when the opioid receptor antagonist naloxone $(20 \mu \mathrm{M})$ was added to such cells, no current increase was observed $(n=3)$ (data not shown), suggesting that naloxone, unlike norBNI, is a neutral antagonist. norBNI is known to bind at $\kappa_{1}$ receptors with affinities in the range of 0.5-1.2 nм (Prather et al., 1995; Simonin et al., 1995) and completely blocks opioid agonist stimulation of adenylyl cyclase at 100 
A. $\alpha 1 B+\kappa_{1} R$ songongoroon
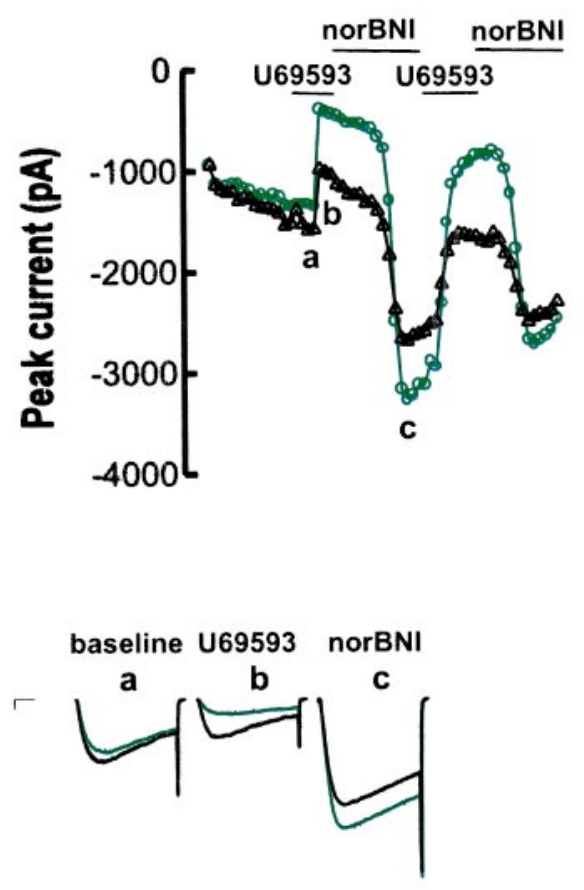

B.

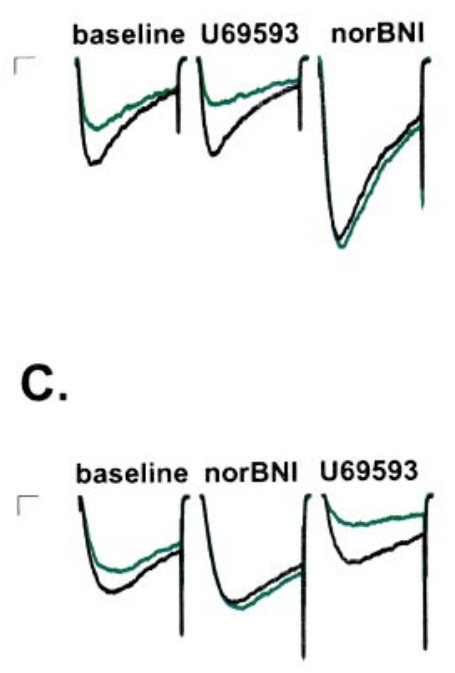

D. $\alpha 1 B+\delta R$

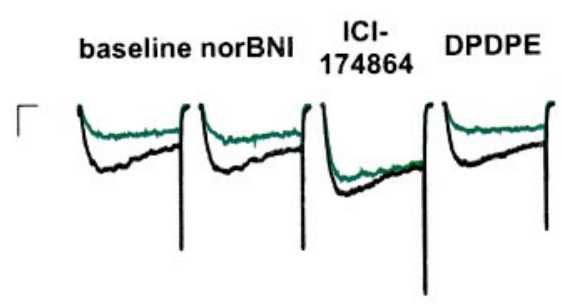

Figure 1. Opioid agonist and inverse agonist effects on $\mathrm{Ba}$ currents for $\alpha_{1 \mathrm{~B}-1^{-}}$ and $\kappa_{1}$ R-expressing tsA-201 cells. $A$, Peak current amplitudes and representative currents before prepulse (green) and after a $30 \mathrm{msec}$ depolarizing prepulse (black), illustrating the effects of the addition to the bath of $1 \mu \mathrm{M}$ U69593 or 100 nM norBNI. Currents were taken from the points indicated. Currents were evoked by a $50 \mathrm{msec}$ depolarization to $0 \mathrm{mV}$ from a holding potential of $-90 \mathrm{mV}$. Calibration: $250 \mathrm{pA}, 10 \mathrm{msec}$. $B$, Representative currents illustrating relatively small current inhibition after U69593 exposure and relatively large current enhancement after norBNI exposure in cells with a large degree of modulation (as indicated by a relatively large increase in current amplitudes after a prepulse) before agonist exposure. $C$, Representative currents illustrating the effects of $100 \mathrm{~nm}$ norBNI added before $1 \mu \mathrm{M}$ U69593. $D$, Currents evoked from a $\alpha_{1 \mathrm{~B}-1^{-}}$and $\delta \mathrm{R}$-expressing cell in the presence of $100 \mathrm{~nm}$ norBNI, $1 \mu \mathrm{M}$ ICI-174864, and $1 \mu \mathrm{M}$ DPDPE. nм (Avidor-Reiss et al., 1995). Because norBNI was applied in the absence of agonist and reduced prepulse ratios to that seen in untransfected cells, we believe that maximal relief of agonistindependent modulation was obtained with $100 \mathrm{~nm}$ norBNI.

Both the U69593 (inhibitory) and norBNI (enhancing) effects in these experiments could be completely blocked by pertussis toxin $(n=5)$, and cells responsive to one drug were always responsive to the other. When $50 \mu \mathrm{M}$ GF109203, a specific PKC inhibitor, was included in the intracellular solution $(n=3)$, the response of $\alpha_{1 \mathrm{~B}-1^{-}}$and $\kappa_{1}$ R-expressing cells to U69593 and norBNI was unaltered relative to cells without GF109203 in the intracellular solution, suggesting that PKC-mediated phosphorylation plays no role in the observed effects on the currents (data not shown).

To further verify that norBNI does in fact act by relieving agonist-independent G-protein modulation, the effects of receptor expression, U69593, and norBNI on current facilitation as determined by current ratios were examined (Ikeda, 1991) and were defined as the ratio of the current amplitude after a prepulse, $I(+\mathrm{pp})$ to that before a prepulse, $I(-\mathrm{pp})$. Baseline current ratios (before drug exposure) for $\alpha_{1 \mathrm{~B}-1^{-}}$and $\kappa_{1}$ R-expressing cells (ratio, $1.05 \pm 0.08 ; n=13$ ) were significantly greater than for cells not expressing $\kappa_{1} \mathrm{R}$ (data pooled from $\kappa_{1} \mathrm{R}$-untransfected cells and U69593- and norBNI-unresponsive cells; ratio, $0.89 \pm 0.05$; $n=13 ; p<0.05$, one-tailed $t$ test). These ratios were significantly correlated with the degree of current enhancement obtained after the addition of norBNI (baseline relative to peak of norBNI effect; $r=0.84 ; p<0.001 ; n=13$ ) (Fig. 1, compare $A, B$ ), suggesting that cells most responsive to norBNI expressed the highest levels of agonist independent modulation. The effects of U69593 and norBNI on current amplitudes were mirrored in terms of the current ratios. At baseline, before drug exposure, a small degree of facilitation was seen (ratio, $1.05 \pm 0.08$ ), facilitation increased in the presence of U69593 (ratio, $1.70 \pm 0.13$ ), and currents inactivated to a small extent after a prepulse in the presence of norBNI (ratio, $0.78 \pm 0.03 ; n=13$ in all cases) (Fig. 1). This current inactivation after a prepulse, as a consequence of a reduction in active G-protein, is similar to the results of Ikeda (1992), who found that internal perfusion of rat sympathetic neurons with GDP $\beta$ S caused inactivation after a prepulse at most prepulse potentials. In summary, these results suggest that the currents were inhibited to an intermediate degree before drug exposure, that the agonist U69593 rapidly caused additional current inhibition, and that norBNI is actually an inverse agonist, relieving both the agonist-independent and agonist-dependent inhibition of the current.

Because this agonist-independent receptor activity is likely to complicate estimates of receptor effects on $\mathrm{Ca}$ channels, we used U69593 to observe currents in the presence of maximum receptor activity, $I\left(\mathrm{R}^{*}\right)$, and norBNI to observe currents in the presence of inactive receptor, $I(\mathrm{R})$. An index of total modulation was estimated from the peak of the U69593 response [an estimate of $\left.I\left(\mathrm{R}^{*}\right)\right]$ and the peak of the norBNI response (in the case of cells showing agonist-independent modulation) or baseline currents (in the case of cells without agonist-independent modulation) to estimate $I(\mathrm{R})$. Total modulation was then defined as 
$\left[I(\mathrm{R})-I\left(\mathrm{R}^{*}\right)\right] / I(\mathrm{R})$. In the case of $\alpha_{1 \mathrm{~B}-1^{-}}$expressing cells, modulation was $68.9 \pm 3.7 \%(n=13)$ (see Fig. 5) when defined in this way and $47 \pm 6.4 \%(n=13)$ when defined as [I(baseline) $\left.I\left(\mathrm{R}^{*}\right)\right] / I$ (baseline), suggesting a nearly $50 \%$ reduction in the SEM of the estimated effect size. Consistent with the involvement of heterotrimeric G-proteins (Marchetti et al., 1986; Ikeda, 1991; Pollo et al., 1992), this current reduction was greater with respect to currents evoked before a voltage prepulse than for currents evoked after a prepulse (total modulation, $38.6 \pm 3.7 \%$ after prepulse; $n=13$ ) (Fig. 1). Kinetic slowing was evident in the majority of cells (Fig. 1) but was not examined in detail for the purpose of this study.

To further explore the specificity of agonist-independent opioid receptor effects on $\mathrm{Ca}$ currents, we transfected cells with $\alpha_{1-\mathrm{B} 1}, \beta_{1 \mathrm{~B}}, \alpha_{2 \mathrm{~B}}, \mathrm{CD} 8 \alpha$, and the mouse $\delta$-opioid receptor $(\delta \mathrm{R})$. This receptor has well characterized agonist-independent activity; ICI174,864 is known to act as an inverse agonist, and DPDPE (enkephalin, [D-Pen ${ }^{2,5}$ ) is known to act as an agonist (Chiu et al., 1996; Mullaney et al., 1996; Merkouris et al., 1997). These cells showed inhibition and prepulse facilitation qualitatively similar to $\kappa_{1}$ R-expressing cells before drug exposure (Fig. 1D). When norBNI was added to the bath, $\delta \mathrm{R}$-expressing cells showed no alteration in their $\alpha_{1 \mathrm{~B}-1}$ currents (Fig. $1 D ; n=3$ ). However, when ICI174,864 was added to the bath, an increase in current amplitudes was noted $(28.0 \pm 14.0 \% ; n=3)$, and facilitation decreased (current ratio, $1.4 \pm 0.2$ at baseline; current ratio, $1.0 \pm 0.1$ in the presence of ICI174,864). When DPDPE was subsequently added to the bath, current amplitudes rapidly decreased and facilitation increased (current ratio, $1.5 \pm 0.4$ ), and the DPDPE-mediated inhibition could be reversed by reapplication of ICI174,864 over a time frame of minutes (total modulation, $37.0 \pm 13.0 \% ; n=3$ ). The response of these cells to agonist and inverse agonist was therefore qualitatively similar to cells expressing $\kappa_{1} \mathrm{R}$ but selective for $\delta \mathrm{R}$-specific agents.

When $\kappa_{1} \mathrm{R}$ - and $\alpha_{1 \mathrm{E}-3}$-expressing cells were exposed to U69593 and norBNI, much less current inhibition $(25.3 \pm 1.9 \% ; n=11)$ (Fig. 2; see Fig. 5) was observed than for $\alpha_{1 \mathrm{~B}-1}$-expressing cells $(p<0.001)$, consistent with previous findings (Toth et al., 1996; Yassin et al., 1996). $\alpha_{1 \mathrm{E}-3^{-}}$-expressing cells also showed partial voltage-dependent relief of inhibition such that inhibition after a prepulse was less than before a prepulse (total modulation, $21.9 \pm$ $1.6 \%$ after prepulse), but cells fell far short of the $\sim 50 \%$ relief seen in $\alpha_{1 \mathrm{~B}-1}$-expressing cells. Prepulse ratios in the presence of U69593 corrected for inactivation (see Materials and Methods) were $1.052 \pm 0.02$ for $\alpha_{1 \mathrm{E}-3}$-expressing cells but $2.184 \pm 0.02$ for $\alpha_{1 \mathrm{~B}-1}$-expressing cells $(p<0.001$; see Fig. 5 ).

\section{Structural determinants of G-protein regulation}

To elucidate the structural basis for differences in the degree of G-protein regulation of $\alpha_{1 \mathrm{~B}-1}$ and $\alpha_{1 \mathrm{E}-3} \mathrm{Ca}$ channels, we constructed Ca channels in which portions of $\alpha_{1 \mathrm{~B}-1}$ were inserted into an $\alpha_{1 \mathrm{E}-3}$ background. When the entire N-terminal half of $\alpha_{1 \mathrm{~B}-1}$ was transferred into the $\alpha_{1 \mathrm{E}-3}$ background to create the bBbBbEeEe chimera (where lowercase letters indicate intracellular sequence, and uppercase letters indicate transmembrane domains, written in the sequence $\mathrm{N}$ terminus, domain I, I/II loop, etc.), currents were markedly reduced by U69593 and markedly enhanced by norBNI (Fig. 3; see Fig. 5) $(n=7)$. Overall modulation was $69.4 \pm 4.3 \%$ and not significantly different from modulation seen with $\alpha_{1 \mathrm{~B}-1}$. Inhibition was partially relieved by a voltage prepulse (to $46 \pm 7.9 \%$ ), and somewhat less relief was
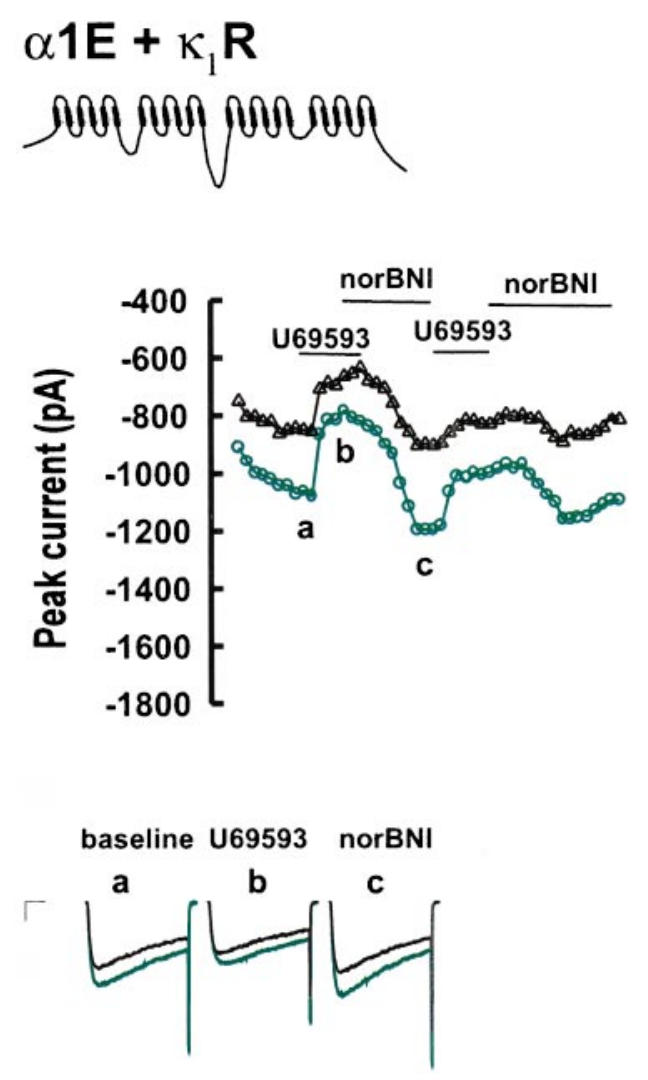

Figure 2. Opioid agonist and inverse agonist effects on Ba currents for $\alpha_{1 \mathrm{E}-3^{-}}$and $\kappa_{1} \mathrm{R}$-expressing tsA-201 cells. Currents were taken from the points indicated. Calibration: $250 \mathrm{pA}, 10 \mathrm{msec}$. See Figure 1 for details.

seen than for $\alpha_{1 \mathrm{~B}-1}$ (corrected prepulse ratio, $1.78 \pm 0.20 ; p>$ 0.05; see Fig. 5).

To determine the minimal sequence responsible for these observations, we transferred two of the intracellular loops contained in the bBbBbEeEe chimera into the $\alpha_{1 \mathrm{E}-3}$ background, individually and in combination. The I/II intracellular loop has been shown by GST fusion studies to bind $\beta \gamma$ G-protein subunits (De Waard et al., 1997) and to posses a consensus sequence QXXER that it shares with adenyl cyclase and number of other G-protein effectors (Pragnell et al., 1994). Somewhat consistent with the results of Page et al. (1997), the eEbEeEeEe chimera (Figs. 4-6) showed current inhibition that was slightly greater but not significantly different from $\alpha_{1 \mathrm{E}-3}(33.8 \pm 2.3 \% ; n=9)$ and much less than that of $\alpha_{1 \mathrm{~B}-1}(p<0.001)$ or the bBbBeEeE chimera $(p<$ $0.001)$. When the II/III intracellular loop of $\alpha_{1 \mathrm{~B}-1}$ was transferred into the $\alpha_{1 \mathrm{E}-3}$ background (Figs. 4, 5, eEeEbEeEe chimera), inhibition similar to that of $\alpha_{1 \mathrm{E}-3}$ was seen $(23.1 \pm 4.8 \% ; n=7)$. When the II/III loop was transferred into the $\alpha_{1 \mathrm{E}-3}$ background, in combination with the I/II loop (Figs. 4, 5, eEbEbEeEe chimera), the resulting construct also showed inhibition similar to that of $\alpha_{1 \mathrm{E}-3}(24.6 \pm 1.1 \% ; n=8)$. All three constructs showed prepulse facilitation similar to $\alpha_{1 \mathrm{E}-3}(p>0.05$ in each case $)$ and significantly less facilitation than $\alpha_{1 \mathrm{~B}-1}(p<0.001$ for each).

Because the I/II loop alone failed to significantly enhance modulation but may play some role in mediating the binding of $\beta \gamma$ subunits to Ca channels (De Waard et al., 1997), a series of additional constructs was created to assess the role of sequences near the I/II loop in determining effector sensitivity. When domain II, the I/II loop, and the II/III loop from $\alpha_{1 \mathrm{~B}-1}$ were 

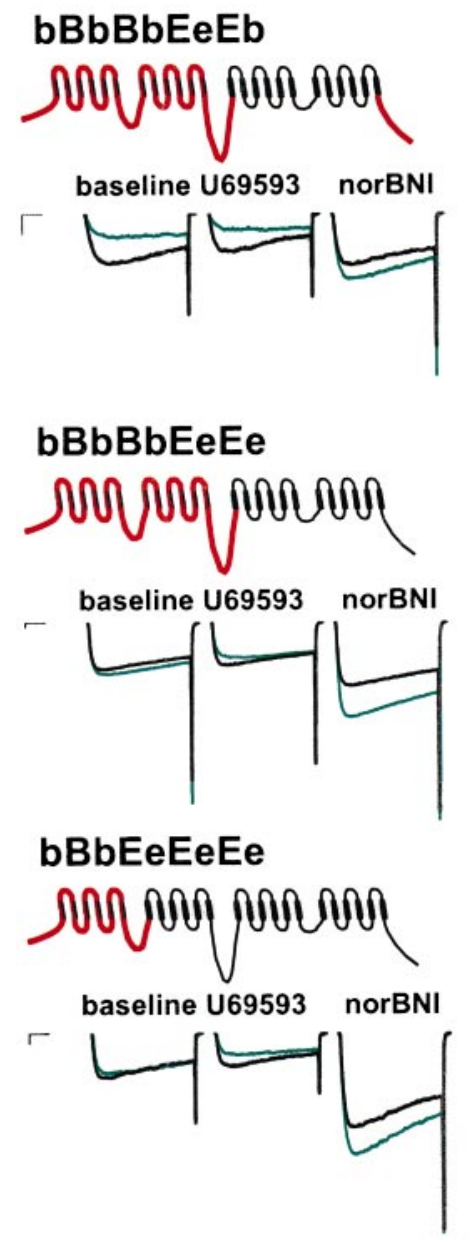
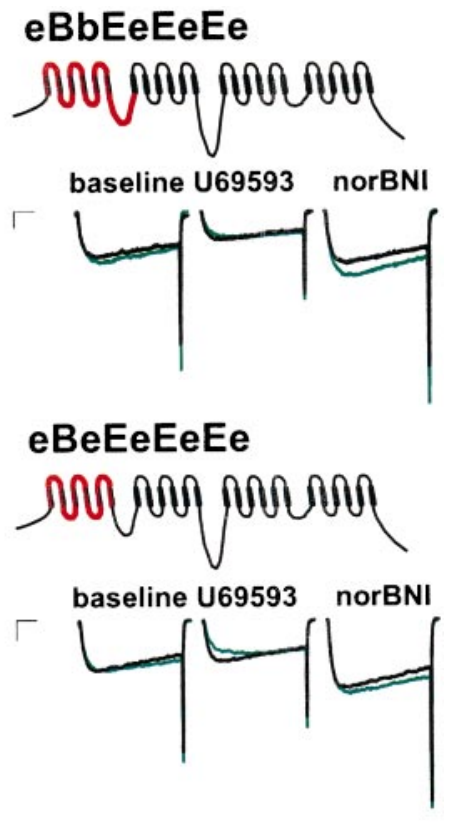

Figure 3. Representative currents from various $\alpha_{1 \mathrm{~B}-1}$ and $\alpha_{1 \mathrm{E}-3}$ chimeric $\mathrm{Ca}$ channels with sensitivity to modulation approaching that of native $\alpha_{1 \mathrm{~B}-1}$ channels (Fig. 1) before prepulse (green) and after a 30 msec depolarizing prepulse (black). Maximal effects of U69593 and norBNI are illustrated. Calibration: $250 \mathrm{pA}, 10 \mathrm{msec}$. transferred into the $\alpha_{1 \mathrm{E}-3}$ background (eEbBbEeEe chimera), modulation and facilitation similar to that of $\alpha_{1 \mathrm{E}-3}$ was obtained (total modulation, $24.6 \pm 1.1 \% ; p>0.05$; corrected ratio, $1.03 \pm$ $0.02 ; p>0.05 ; n=8)$. The addition of $\alpha_{1 \mathrm{~B}-1}$ sequence from the $\mathrm{N}$ terminus to the C-terminal end of the I/II loop into the $\alpha_{1 \mathrm{E}-3}$ background (Figs. 3, 5, 6, bBbEeEeEe chimera) resulted in a channel showing inhibition not significantly different from $\alpha_{1 \mathrm{~B}-1}$ $(66.6 \pm 4.1 \% ; n=8)$. However, as in the case of the bBbBbEeEe chimera, this inhibition was less completely relieved by a prepulse (to $46.0 \pm 7.9 \%$; corrected prepulse ratio, $1.55 \pm 0.11 ; p<0.001$ ) than in the case of $\alpha_{1 \mathrm{~B}-1}$, although facilitation was greater than that seen in the case of $\alpha_{1 \mathrm{E}-3}(p<0.05)$. When domain I and the I/II loop from $\alpha_{1 \mathrm{~B}-1}$ were transferred alone into the $\alpha_{1 \mathrm{E}-3}$ background (Figs. 3, 5, eBbEeEeEe chimera) modulation that was not significantly different from $\alpha_{1 \mathrm{~B}-1}$ was also observed (56.8 $\pm 4.4 \%$; $n=7 ; p>0.05$ ). These channels showed less facilitation (corrected prepulse ratio, $1.27 \pm 0.05)$ than $\alpha_{1 \mathrm{~B}-1}$-expressing cells $(p<0.001)$ and not significantly more facilitation than $\alpha_{1 \mathrm{E}-3^{-}}$ expressing cells $(p>0.05)$. We also attempted to examine the contribution of the $\mathrm{N}$ terminus in isolation by the chimera bEeEeEeEe but were unable to obtain adequate current expression from this chimera. When domain I of $\alpha_{1 \mathrm{~B}-1}$ was transferred alone into the $\alpha_{1 \mathrm{E}-3}$ background (Figs. 3, 5, eBeEeEeEe chimera), modulation significantly greater than $\alpha_{1 \mathrm{E}-3}$ was observed (44.6 \pm $0.03 \% ; n=10 ; p<0.001)$, but this was significantly less than that observed for $\alpha_{1 \mathrm{~B}-1}(p<0.05)$. Facilitation (corrected ratio, $1.3 \pm$ $0.02)$ was not significantly different from $\alpha_{1 \mathrm{E}-3}(p>0.05)$.

Domain I of $\mathrm{Ca}$ channels is thought to be partly responsible for determining the voltage dependence of $\mathrm{Ca}$ channel inactivation (Zhang et al., 1994), although the C terminus (Klockner et al., 1995; Soldatov et al., 1997) and I/II loop (Herlitze et al., 1997) are also thought to play a role. The regions in domain I responsible for determining inactivation are thought to be a C-terminal portion of the $I_{\mathrm{s} 5}$ sec6 linker as well as $I_{\mathrm{s} 6}$ (Zhang et al., 1994). When this sequence alone was added along with the I/II loop (Figs. 4, 5, eE $E_{(90-309)} B_{(315-355)} b E e E e E e$ chimera), the resulting construct showed modulation $(30.0 \pm 3.9 \% ; n=7)$ and facilitation (corrected ratio, $1.04 \pm 0.01$ ) similar to $\alpha_{1 \mathrm{E}-3}$ and the eEbEeEeEe chimera ( $p>0.05$ in both cases), although inactivation was reduced compared with the eEbEeEeEe chimera $(p<0.05)$.

Recently Qin et al. (1997) have provided biochemical and functional evidence that the $\mathrm{C}$ terminus of non-DHP-sensitive $\mathrm{Ca}$ channels is involved in $\beta \gamma$ binding and current inhibition. To assess the role of the $C$ terminus in our system, we exchanged the $\mathrm{C}$ terminus of $\alpha_{1 \mathrm{~B}-1}$ into the bBbBbEeEe chimera to produce the bBbBbEeEb chimera (Figs. 3, 5). These channels showed inhibition $(65.6 \pm 4.2 \% ; n=7)$ not significantly different from $\alpha_{1 \mathrm{~B}-1}$ or the bBbBbEeEe chimera $(p>0.05$ in both cases). However, facilitation more closely approximated that of $\alpha_{1 \mathrm{~B}-1}$ than was seen in the case of the bBbBbEeEe chimera (corrected ratio, $2.04 \pm 0.12)$.

Because $\mathrm{Ca}$ channel modulation by G-proteins is voltagedependent, we collected current-voltage data in the presence of norBNI and U69593 for a number of the constructs (Fig. 6). The bBbBbEeEb chimera $(n=7)$ closely resembled wild-type $\alpha_{1 \mathrm{~B}-1}$ $(n=5)$ both in terms of inhibition and facilitation (Fig. 6). As we 


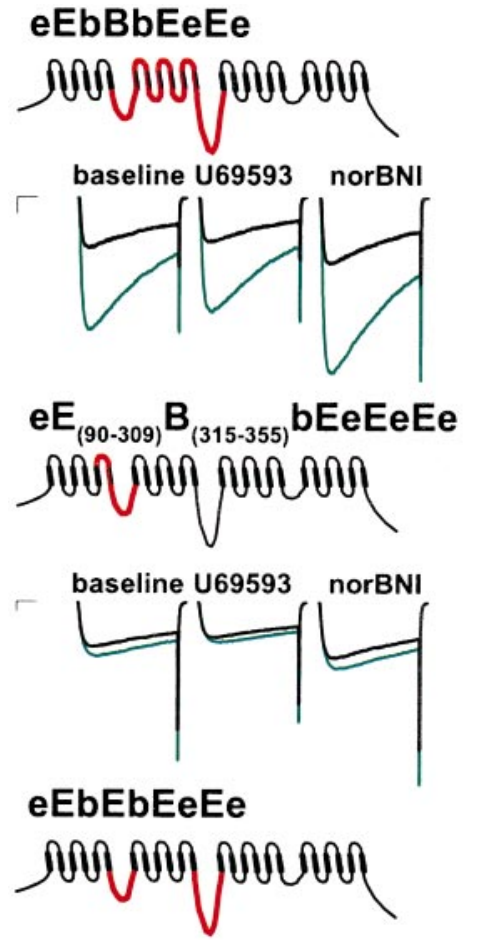

Figure 4. Representative currents from various $\alpha_{1 \mathrm{~B}-1}$ and $\alpha_{1 \mathrm{E}-3}$ chimeric Ca channels with sensitivity to modulation approaching that of native $\alpha_{1 \mathrm{E}-3}$ channels (Fig. 2) before prepulse (green) and after a $30 \mathrm{msec}$ depolarizing prepulse (black). Maximal effects of U69593 and norBNI are illustrated. Calibration: $250 \mathrm{pA}, 10 \mathrm{msec}$.

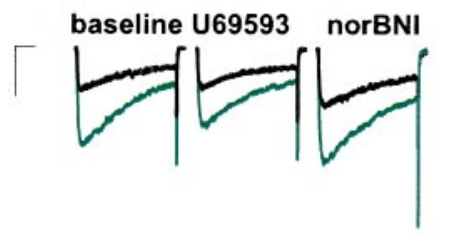

eEbEeEeEe

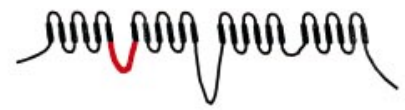

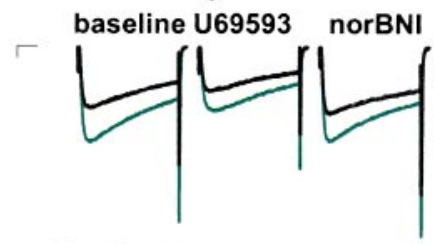

eEeEbEeEe
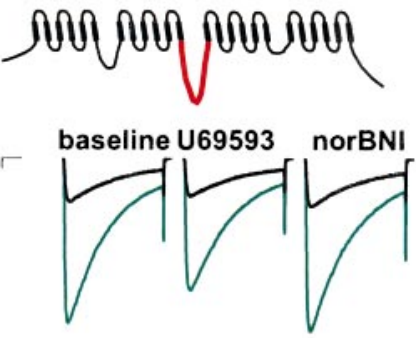

observed using a single test potential of $0 \mathrm{mV}$, the bBbBbEeEe construct $(n=5)$ showed less facilitation than bBbBbeEb across a range of activating potentials (Fig. 6). These results suggest that the $\mathrm{C}$ terminus may be partly responsible for the differences in facilitation between $\alpha_{1 \mathrm{~B}-1}$ and $\alpha 1_{\mathrm{E}-3}$, but it does not appear to mediate the differences in inhibition between the two channels. The bBbEeEeEe chimera $(n=5)$ showed strong inhibition, similar in magnitude to $\alpha_{1 \mathrm{~B}-1}$, but showed little facilitation at any activating potential. The eEbEeEeEe chimera (Fig. $6 ; n=8$ ) showed relatively little facilitation or inhibition at any activating potential. For example, at a potential of $-10 \mathrm{mV}$, the current ratio in the presence of U69593 for $\alpha_{1 \mathrm{~B}-1}(2.28 \pm 0.34)$ was not significantly different from the bBbBbEeEb chimera $(2.00 \pm 0.20$; $p>0.05)$ but was significantly greater than the ratios for the bBbEeEeEe (1.22 \pm 0.11), eEbEeEeEe $(0.92 \pm 0.04)$, and bBbBbEeEe $(1.40 \pm 0.11)$ chimeras (all $p<0.05)$. These data further reinforce the conclusion that facilitation and inhibition are mediated by different structural elements.

We defined agonist-independent modulation as the difference in the current amplitude in the presence of norBNI compared with that at baseline. The degree of such modulation would be expected to correlate with the index of total modulation for a particular construct if both indices reflect sensitivity to inhibition by G-proteins. We computed this correlation across all of our observations and found that the correlation was large and highly significant ( $r=0.74 ; p<0.00001)$. In addition, the magnitude of the agonist-independent modulation seen for each construct was well correlated with the magnitude of the total modulation seen for the construct $\left(0.03 \pm 0.01 \%, \alpha_{1 \mathrm{E}-3} ; 0.02 \pm 0.01 \%\right.$, eE-
bEeEeEe; $0.22 \pm 0.03 \%$, eBeEeEeEe; $\left.0.38 \pm 0.06 \%, \alpha_{1 \mathrm{~B}-1}\right)$ This provides additional support for the notion that the index of total modulation is indeed a valid index of sensitivity to current inhibition by G-proteins.

We were concerned that the observed differences in facilitation between the constructs were attributable to differences in the kinetics of G-protein association with the channels. We measured the G-protein reassociation rates for a number of our constructs using a variable interval between the prepulse and the second test pulse. Facilitation decayed as a single exponential with time constants between the limits of $15.9 \pm 2.3 \mathrm{msec}(\mathrm{eEbEeEeEe} ; n=$ 4) (data not shown) and $41.6 \pm 2.4 \mathrm{msec}\left(\alpha_{1 \mathrm{~B}-1} ; n=6\right)$ (data not shown). Facilitation will have decayed to $73-89 \%$ of its maximum after a $5 \mathrm{msec}$ interval for our constructs. Therefore, the large differences in facilitation observed (Figs. 5, 6) cannot be accounted for by differences in reassociation kinetics.

As noted above, current ratios (Fig. 5) were corrected for inactivation to facilitate comparisons between constructs that differed markedly in terms of inactivation. An adequate kinetic model that can account for modulation, activation, and inactivation of $\mathrm{Ca}$ channels has not yet been elaborated, and the relationship between inactivation and modulation therefore remains unclear. However, with respect to the most important constructs used in the present study, it is clear that modulation and inactivation are relatively independent. For example, the constructs bBbBbEeEb, bBbBbEeEe, bBbEeEeEe, eBbEeEeEe, eBeEeEeEe, and e $\left(E_{90-309} B_{315-355}\right)$ bEeEeEe did not differ in terms of inactivation compared with $\mathrm{bBbBbBbBb}$ (all $p>0.9$ ). However, these constructs differed markedly from one another in 


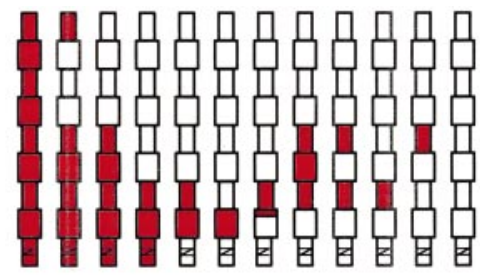

A.

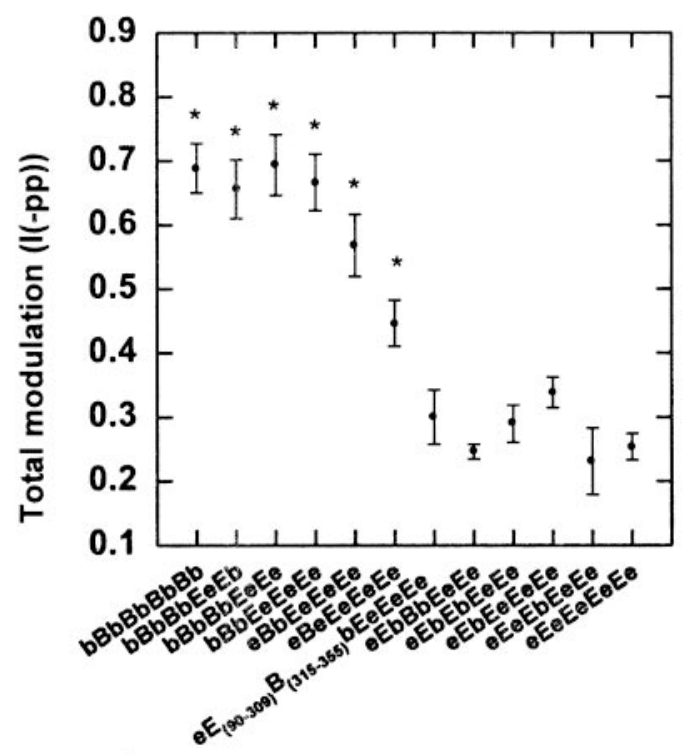

B.

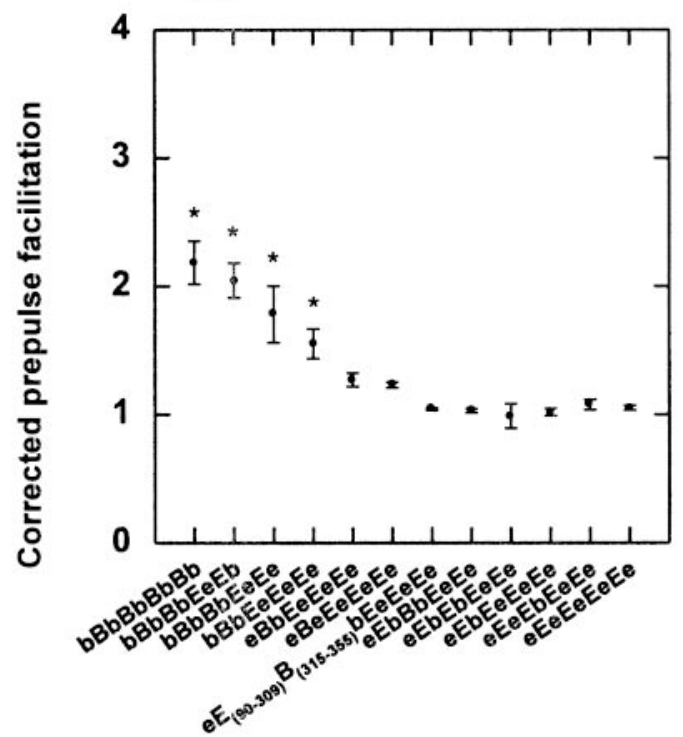

Figure 5. Summary of inhibition and facilitation seen in native $\alpha_{1 \mathrm{~B}-1^{-}}$and $\alpha_{1 \mathrm{E}-3^{-}}$-expressing cells as well as for various chimeric $\mathrm{Ca}$ channels. $A$, Summary of $\kappa_{1} \mathrm{R}$ inhibition obtained for Ba currents evoked before a depolarizing prepulse from native $\alpha_{1 \mathrm{~B}-1^{-}}$and $\alpha_{1 \mathrm{E}-3^{-}}$-expressing cells, as well as cells expressing various $\alpha_{1 \mathrm{~B}-1}$ and $\alpha_{1 \mathrm{E}-3}$ chimeras. Values are plotted as mean \pm SEM. Sample sizes for each construct were $\geq 6$ as detailed in Results. Asterisks indicate modulation significantly different from native $\alpha_{1 \mathrm{E}-3}(p<0.05)$. B, Summary of corrected $\kappa_{1} \mathrm{R}$-mediated prepulse facilitation ratios from native $\alpha_{1 \mathrm{~B}-1^{-}}$and $\alpha_{1 \mathrm{E}-3^{-}}$-expressing cells, as well as cells expressing various $\alpha_{1 \mathrm{~B}-1}$ and $\alpha_{1 \mathrm{E}-3}$ chimeras. Values are plotted as mean \pm SEM. Ratios were calculated by multiplying prepulse ratios in the presence of $\mathrm{U} 69593[I(+\mathrm{pp}) / I(-\mathrm{pp})]$ by an index of inactivation $[I(-\mathrm{pp}) / I(+\mathrm{pp})]$ calculated from currents in the presence of norBNI to adjust for differences in inactivation between the various constructs. Sample sizes for each construct were $\geq 6$ as detailed in Results. Asterisks indicate facilitation significantly different from native $\alpha_{1 \mathrm{E}-3}(p<0.05)$. terms of facilitation. The chimeras $\mathrm{bBbBbEeEb}$ and $\mathrm{bBbBbEeEe}$ did not differ significantly from $\alpha_{1 \mathrm{~B}-1}$ in terms of facilitation $(p>$ 0.1 , but bBbEeEeEe, eBbEeEeEe, eBeEeEeEe, and e(EB)bEeEeEe did differ significantly (all $p<0.0001$ ). Because these constructs differ greatly in terms of facilitation but not in terms of inactivation, it seems clear that the two are not highly correlated.

\section{DISCUSSION}

We have identified a domain in the family of DHP-insensitive Ca channels that appears to largely dictate the efficacy of G-proteininduced channel inhibition. The results of the present study also suggest that the $\kappa_{1} \mathrm{R}$, like the $\delta \mathrm{R}$ (Chiu et al., 1996; Mullaney et al., 1996; Merkouris et al., 1997), has agonist-independent activity that can be suppressed by drugs with inverse-agonist properties. Therefore, it appears that these pharmacological properties may be general characteristics of the opioid receptor family. Agonistindependent activity of the $\kappa_{1} \mathrm{R}$ has not been previously reported. It is likely that we observed such activity in our experiments because of the high transient expression levels obtainable in tsA-201 cells or because of some other cell-dependent variables. The observation of this agonist-independent activity allowed us to identify norBNI as an inverse agonist at the $\kappa_{1} \mathrm{R}$. The use of inverse agonists in combination with agonists appears to have important utility in that receptor states near maximal and minimal activity can be readily generated, allowing for more precise estimates of receptor effects on G-protein regulated effectors. This consideration would theoretically be of greatest importance for systems with the highest levels of receptor expression, that would be expected to exhibit significant agonist-independent receptor activity. We achieved substantial improvements in the precision of our estimates of G-protein modulation by using this approach.

With regard to the structural basis for the differences in G-protein sensitivity between $\alpha_{1 \mathrm{~B}-1}$ and $\alpha_{1 \mathrm{E}-3}$ Ca channels, the results of the present study suggest that domain I of $\alpha_{1-\mathrm{B} 1}$ is the single most important structural feature required for determining the higher sensitivity to opioid receptor modulation of $\alpha_{1 \mathrm{~B}-1}$ compared with $\alpha_{1 \mathrm{E}-3}$. Whereas $\kappa_{1}$ R-mediated modulation of $\alpha_{1 \mathrm{E}-3}$ was only $37 \%$ of that obtained for native $\alpha_{1 \mathrm{~B}-1}$ channels, exchange of domain I alone yielded a chimeric channel with $65 \%$ of the modulation of $\alpha_{1 \mathrm{~B}-1}$. The further addition of the I/II linker increased modulation to $83 \%$ of native $\alpha_{1 \mathrm{~B}-1}$ channels, and the further addition of the $\mathrm{N}$ terminus increased modulation to $100 \%$ of $\alpha_{1 \mathrm{~B}-1}$ (Fig. 5). These same regions appear largely responsible for facilitation, although the determinants of facilitation appear to be complex and may also include the $\mathrm{C}$ terminus (Figs. 5, 6). The lack of significant differences in modulation between the eEbEeEeEe chimera and native $\alpha_{1 \mathrm{E}-3}$ (Fig. 5) suggests that the I/II loop is not sufficient to determine the differential sensitivity to modulation between $\alpha_{1 \mathrm{~B}-1}$ and $\alpha_{1 \mathrm{E}-3}$. Likewise, the lack of significant differences in inhibition between the bBbBbEeEe and bBbBbEeEb chimeras (Fig. 5) suggests that the $\mathrm{C}$ terminus is not involved in determining differences in sensitivity to modulation. Therefore, the two structural elements shown to be involved in G-protein $\beta \gamma$ binding to Ca channels (De Waard et al., 1997; Qin et al., 1997; Zamponi et al., 1997) do not appear to account for differences in sensitivity to inhibition between $\alpha_{1 \mathrm{~B}-1}$ and $\alpha_{1 \mathrm{E}-3}$.

The role of the I/II loop in G-protein modulation of $\mathrm{Ca}$ channels is controversial. A number of other studies have also suggested that the I/II loop is not sufficient to account for high sensitivity to G-protein modulation. Page et al. (1997) showed that transfer of the I/II loop from $\alpha_{1 \mathrm{~B}}$ to $\alpha_{1 \mathrm{E}}$ or from $\alpha_{1 \mathrm{~B}}$ to $\alpha_{1 \mathrm{~A}}$ 

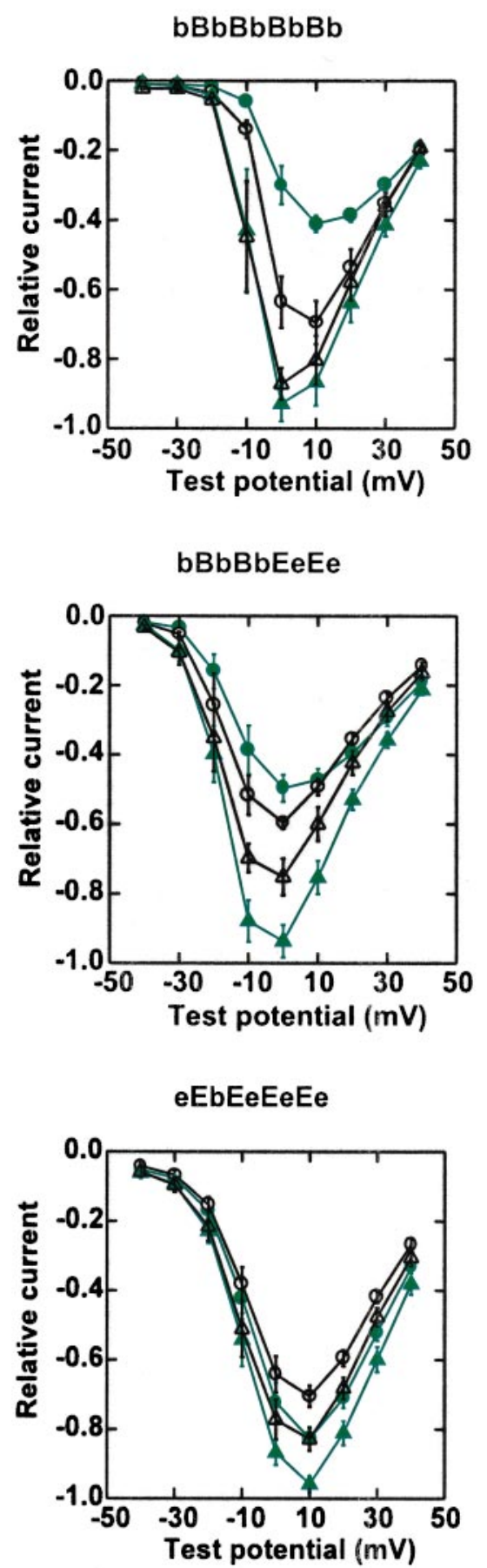
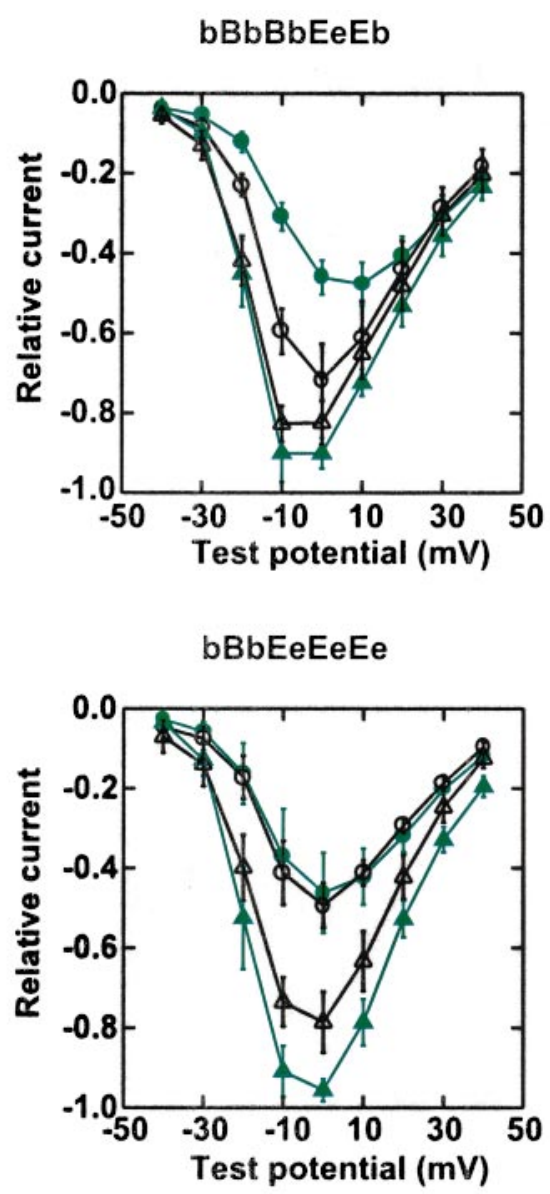

- U69593, -pp

○ U69593, +pp

$\Delta$ norBNI, -pp

$\Delta$ norBNI, $+p p$

Figure 6. Current-voltage relations for selected Ca channel constructs in the presence of U69593 (circles) and norBNI (triangles) before (green) and after (black) a depolarizing prepulse $(p p)$. Sample sizes were $\geq 5$ as detailed in Results.

conferred kinetic slowing but not inhibition on the recipient channel. Qin et al. (1997) showed that transfer of the I/II loop from $\alpha_{1 \mathrm{C}}$ to $\alpha_{1 \mathrm{E}}$ yielded a chimeric channel that was still modulated like $\alpha_{1 \mathrm{E}}$. Z hang et al. (1996) showed that transfer of the I/II loop from $\alpha_{1 \mathrm{~A}}$ or $\alpha_{1 \mathrm{C}}$ into $\alpha_{1 \mathrm{~B}}$ yielded a channel that was still modulated like $\alpha_{1 \mathrm{~B}}$. In contrast, Zamponi et al. (1997) showed that transfer of the I/II loop from $\alpha_{1 \mathrm{~B}}$ into $\alpha_{1 \mathrm{~A}}$ yielded a chimeric channel with significantly more modulation than native $\alpha_{1 \mathrm{~A}}$. Herlitze et al. (1997) and De Waard et al. (1997) showed that mutations in the sequence QXXER of $\alpha_{1 \mathrm{~A}}$ can disrupt modulation, and peptides made according to sequences in the I/II loop can block modulation of both channels (Zamponi et al., 1997). In addition, a number of groups have demonstrated that the I/II loop can indeed bind $\beta \gamma$ subunits (De Waard et al., 1997; Qin et al., 1997; Zamponi et al., 1997), and this may be important in mediating the effects of $\beta \gamma$ subunits in some general way. The results of Qin et al. (1997) and Zhang et al. (1996) also suggest that the $\mathrm{C}$ terminus plays a critical role in mediating modulation, and the latter study suggests a role of the $\mathrm{N}$ terminal portion of the $\mathrm{Ca}$ channel that is $\mathrm{N}$-terminal to the I/II loop. Overall, the results of the present study are most consistent with those of Zhang et al. (1996) in terms of the involvement of the $\mathrm{N}$ terminal 
portion of the channel, although we find that the $\mathrm{C}$ terminus plays little if any role in determining inhibition.

There are at least three models that could account for the findings of the present study. First, differences in the kinetics of the two channels, probably determined by multiple and complex structural features, could account for at least some of the differences in modulation. For example, we numerically integrated the kinetic model of G-protein modulation proposed by Patil et al. (1996) while systematically varying the rate constants of the model a small amount near their fitted values and have observed alterations in predicted inhibition for each of the rate constants in the model (data not shown). Apart from rate constants directly introduced to model modulation (e.g., "willing" to "reluctant" transitions), predicted inhibition is particularly sensitive to the values of the rate constants for exit from the inactivated state and for transitions between "willing" closed states.

A second model that could account for these data is an allosteric model in which the I/II loop and/or C terminus binds G-protein $\beta \gamma$ subunits and changes conformation but then must induce conformational changes in the gating apparatus of the channel. The $\mathrm{C}$ terminus and I/II loop may interact directly with the gating apparatus or may be coupled to these domains through other structures. According to this view, it is possible that domain I of $\alpha_{1 \mathrm{~B}-1}$, which may itself contain sequence involved in voltagedependent channel gating, is more susceptible to structural alteration by $\beta \gamma$ binding to the $\mathrm{I} / \mathrm{II}$ loop and/or $\mathrm{C}$ terminus than is domain I of $\alpha_{1 \mathrm{E}-3}$, and that the $\mathrm{N}$ terminus somehow facilitates such interactions. Alternatively, domain I may play some role in linking binding to the $\mathrm{C}$ terminus and/or I/II linker to regions of the channel involved in gating to generate modulation.

Finally, it is possible that $\mathrm{Ca}$ channel regions other than the $\mathrm{I} / \mathrm{II}$ loop and $\mathrm{C}$ terminus play a role in $\beta \gamma$ binding. Biochemical binding studies performed to date (Qin et al., 1997; De Waard et al., 1997) have demonstrated that the I/II loop and C terminus have affinities that are by themselves sufficient for tight binding but have not shown that other sequences do not play an important role in $\beta \gamma$ binding to the intact channel. Although domain I (and the $\mathrm{N}$ terminus) may not be competent to bind $\beta \gamma$ subunits in isolation, it is possible that it does contribute to the affinity of $\beta \gamma$ subunit binding to the intact channel and that domain I of $\alpha_{1 \mathrm{~B}-1}$ is differentially capable of stabilizing $\beta \gamma$ binding in comparison to domain I of $\alpha_{1 \mathrm{E}-3}$.

The notion that different structural elements account for facilitation and inhibition is similar to the results of Zhang et al. (1996), who showed that both the first domain and the $\mathrm{C}$ terminus of $\alpha_{1 \mathrm{~B}}$ were required within an $\alpha_{1 \mathrm{~A}}$ background to confer facilitation and inhibition, but $\mathrm{N}$ - or C-terminal halves of $\alpha_{1 \mathrm{~B}}$ in an $\alpha_{1 \mathrm{~A}}$ background were sufficient for inhibition alone. A physical interaction of the $\mathrm{C}$ terminus of $\alpha_{1 \mathrm{~B}-1}$ with $\mathrm{G} \beta \gamma$ subunits may play some role in the functional uncoupling of $\mathrm{G} \beta \gamma$ and $\mathrm{Ca}$ channels after a depolarizing pulse.

Whatever the precise mechanism by which domain I and the $\mathrm{N}$ terminus contribute to $\mathrm{Ca}$ channel modulation, the findings of the present study suggest that $\mathrm{Ca}$ channel sensitivity to G-protein modulation not only is determined by sequences with high-affinity interactions with $\beta \gamma$ subunits but also requires another sequence that is perhaps not directly involved in high-affinity $\beta \gamma$ binding. Domain $\mathrm{I}$ and the $\mathrm{N}$ terminus of the channel appear largely responsible for these differences. The N-terminal tails of the two channels are fairly dissimilar (60\% identity), especially in their $\mathrm{N}$ terminal halves. The only significant regions of dissimilarity between $\alpha_{1 \mathrm{~B}-1}$ and $\alpha_{1 \mathrm{E}-3}$ in domain I fall within the extracellular loops (s1-s2, s3-s4, and s5-s6). One or both of these regions of dissimilarity may therefore account for the observed effects of exchanging domain I between $\alpha_{1 \mathrm{~B}-1}$ and $\alpha_{1 \mathrm{E}-3}$.

\section{REFERENCES}

Avidor-Reiss T, Zippel R, Levy R, Saya D, Ezra V, Barg J, MatusLeibovitch N, Vogel Z (1995) kappa-Opioid receptor-transfected cell lines: modulation of adenylyl cyclase activity following acute and chronic opioid treatments. FEBS Lett 361:70-74.

Bean BP (1992) Whole-cell recording of Ca channel currents. Methods Enzymol 207:181-193.

Boussif O, Zanta MA, Behr JP (1996) Optimized galenics improve in vitro gene transfer with cationic molecules up to 1000 -fold. Gene Ther 3:1074-1080.

Carpenter E, Gent JP, Peers C (1996) Opioid receptor independent inhibition of $\mathrm{Ca} 2+$ and $\mathrm{K}^{+}$currents in NG108-15 cells by the kappa opioid receptor agonist U50488H. NeuroReport 7:1809-1812.

Chen J, DeVivo M, Dingus J, Harry A, Li J, Sui J, Carty DJ, Blank JL, Exton JH, Stoffel RH, Inglese J, Lefkowitz RJ, Logothetis DE, Hildebrandt JD, Iyengar RA (1995) A region of adenylyl cyclase 2 critical for regulation by G-protein beta gamma subunits. Science 268:1166-1169.

Chiu TT, Yung LY, Wong YH (1996) Inverse agonist effect of ICI174,864 on the cloned delta-opioid receptor: role of G-protein and adenylyl cyclase activation. Mol Pharmacol 50:1651-1657.

De Waard M, Liu H, Walker D, Scott VE, Gurnett CA, Campbell KP (1997) Direct binding of G-protein beta-gamma complex to voltagedependent Ca channels. Nature 385:446-450.

Doupnik CA, Pun RYK (1994) G-protein activation mediates prepulse facilitation of $\mathrm{Ca}^{2+}$ channel currents in bovine chromaffin cells. J Membr Biol 140:47-56.

Herlitze S, Garcia DE, Mackie K, Hille B, Scheuer T, Catterall WA (1996) Modulation of Ca2 + channels by G-protein beta gamma subunits. Nature 21:258-262.

Herlitze S, Hockerman GH, Scheuer T, Catterall WA (1997) Molecular determinants of inactivation and G-protein modulation in the intracellular loop connecting domains I and II of the $\mathrm{Ca}$ channel alpha1A subunit. Proc Natl Acad Sci USA 94:1512-1516.

Ho SN, Hunt HD, Horton RM, Pullen JK, Pease LR (1989) Sitedirected mutagenesis by overlap extension using the polymerase chain reaction. Gene 77:51-59.

Horton RM, Hunt HD, Ho SN, Pullen JK, Pease LR (1989) Engineering hybrid genes without the use of restriction enzymes: gene splicing by overlap extension. Gene 77:61-68.

Horton RM, Cai ZL, Ho SN, Pease LR (1990) Gene splicing by overlap extension: tailor-made genes using the polymerase chain reaction. Biotechniques 8:528-535.

Ikeda SR (1991) Double-pulse calcium channel current facilitation in adult rat sympathetic neurons. J Physiol (Lond) 439:181-214.

Ikeda SR (1992) Prostaglandin modulation of $\mathrm{Ca}^{2+}$ channels in rat sympathetic neurones is mediated by guanine nucleotide binding proteins. J Physiol (Lond) 458:339-359.

Ikeda SR (1996) Voltage-dependent modulation of N-type calcium channels by G-protein $\beta \gamma$ subunits. Nature 380:255-258.

Kaneko S, Fukuda K, Yada N, Akaike A, Mori Y, Satoh M (1994) $\mathrm{Ca}^{2}+$ channel inhibition by kappa opioid receptors expressed in $\mathrm{Xe}$ nopus oocytes. NeuroReport 5:2506-2508.

Klockner U, Mikala G, Varadi M, Varadi G, Schwartz A (1995) Involvement of the carboxyl-terminal region of the alpha 1 subunit in voltagedependent inactivation of cardiac $\mathrm{Ca}$ channels. $\mathrm{J}$ Biol Chem 270:17306-17310.

Labrecque J, Fargin A, Bouvier M, Chidiac P, Dennis, M (1995) Serotinergic antagonists differentially inhibit spontaneous activity and decrease ligand binding capacity of the rat 5-hydroxytryptamine type 2C receptor in Sf9 cells. Mol Pharmacol 48:150-159.

Marchetti C, Carbone E, Lux HD (1986) Effects of dopamine and noradrenaline on $\mathrm{Ca}$ channels of cultured sensory and sympathetic neurons of chick. Pflügers Arch 406:104-111.

Margolskee RF, McHendry-Rinde B, Horn R (1993) Panning transfected cells for electrophysiological studies. Biotechniques 15:906-911.

Merkouris M, Mullaney I, Georgoussi Z, Milligan G (1997) Regulation of spontaneous activity of the $\delta$-opioid receptor: studies of inverse agonism in intact cells. J Neurochem 69:2115-2122.

Miller RJ (1990) Receptor-mediated regulation of calcium channels and neurotransmitter release. FASEB J 4:3291-3299. 
Mullaney I, Carr IC, Milligan G (1996) Analysis of inverse agonism at the delta opioid receptor after expression in Rat 1 fibroblasts. Biochem J 315:227-234.

Neter J, Wasserman W, Kutner M (1985) Applied linear statistical models, Ed 2. Homewood, IL: Irwin.

Page KM, Stephens GJ, Berrow NS, Dolphin, AC (1997) The intracellular loop between domains I and II of the B-type Ca channel confers aspects of G-protein sensitivity to the E-type Ca channel. J Neurosci 17:1330-1338.

Patil PG, de Leon M, Reed RR, Dubel S, Snutch TP, Yue DT, (1996) Elementary events underlying voltage-dependent G-protein inhibition of N-type calcium channels. Biophys J 71:2509-2521.

Pollo A, Lovallo M, Sher E, Carbone E (1992) Voltage-dependent noradrenergic modulation of omega-conotoxin-sensitive $\mathrm{Ca} 2+$ channels in human neuroblastoma IMR32 cells. Pflügers Archiv 422:75-83.

Portoghese, PS, Lipkowski, AW, Takemori, AE (1987) Binaltorphimine and nor-binaltorphimine, potent and selective kappa-opioid receptor antagonists. Life Sci 40:1287-1292.

Pragnell M, De Waard M, Mori Y, Tanabe T, Snutch TP, Campbell KP (1994) Ca channel beta-subunit binds to a conserved motif in the I-II cytoplasmic linker of the alpha 1-subunit. Nature 368:67-70.

Qin N, Platano D, Olcese R, Stefani E, Birnbaumer L (1997) Direct interaction of $\mathrm{G} \beta \gamma$ with a c-terminal $\mathrm{G} \beta \gamma$-binding domain of the $\mathrm{Ca}$ channel $\alpha 1$ subunit is responsible for channel inhibition by G-proteincoupled receptors. Proc Natl Acad Sci USA 94:8866-8871.

Rhim H, Miller RJ (1994) Opioid receptors modulate diverse types of calcium channels in the nucleus tractus solitarius of the rat. J Neurosci 14:7608-7615.

Simonin F, Gaveriaux-Ruff C, Befort K, Matthes H, Lannes B, Micheletti G, Mattei MG, Charron G, Bloch B, Kieffer B (1995) kappa-Opioid receptor in humans: cDNA and genomic cloning, chromosomal assignment, functional expression, pharmacology, and expression pattern in the central nervous system. Proc Natl Acad Sci USA 92:7006-7010.

Soldatov NM, Zuhlke RD, Bouron A, Reuter, H (1997) Molecular structures involved in $\mathrm{L}$-type $\mathrm{Ca}$ channel inactivation. Role of the carboxylterminal region encoded by exons $40-42$ in alpha1C subunit in the kinetics and $\mathrm{Ca}$ dependence of inactivation. $\mathrm{J}$ Biol Chem 272:3560-3566.

Tallent M, Dichter MA, Bell GI, Reisine T (1994) The cloned kappa opioid receptor couples to an $\mathrm{N}$-type calcium current in undifferentiated PC-12 cells. Neuroscience 63:1033-1040.

Toth PT, Shekter LR, Ma GH, Philipson LH, Miller RJ (1996) Selective G-protein regulation of neuronal calcium channels. J Neurosci 16:4617-4624.

Yassin M, Zong S, Tanabe T (1996) G-protein modulation of neuronal class E (alpha 1E) Ca channel expressed in GH3 cells. Biochem Biophys Res Commun 220:453-458.

Yasuda K, Raynor K, Kong H, Breder CD, Takeda J, Reisine T, Bell GI (1993) Cloning and functional comparison of kappa and delta opioid receptors from mouse brain. Proc Natl Acad Sci USA 90:6736-6740.

Zamponi GW, Bourinet E, Nelson D, Nargeot J, Snutch TP (1997) Crosstalk between G-proteins and protein kinase $\mathrm{C}$ mediated by the calcium channel alpha1 subunit. Nature 385:442-446.

Zhang JF, Ellinor PT, Aldrich RW, Tsien RW (1994) Molecular determinants of voltage-dependent inactivation in $\mathrm{Ca}$ channels. Nature 372:97-100.

Zhang JF, Ellinor PT, Aldrich RW, Tsien RW (1996) Multiple structural elements in voltage-dependent $\mathrm{Ca} 2+$ channels support their inhibition by G-proteins. Neuron 17:991-1003. 